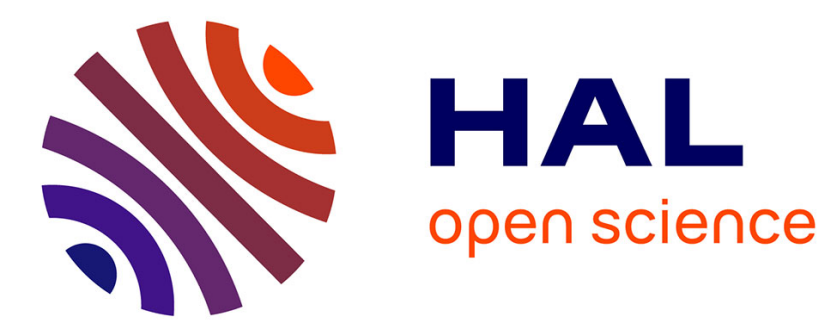

\title{
Thunderstorm-related asthma: what happens and why
} G. d'Amato, C. Vitale, M. d'Amato, L. Cecchi, G. Liccardi, A. Molino, A. Vatrella, A. Sanduzzi, C. Maesano, Isabella Annesi-Maesano

\section{To cite this version:}

G. d'Amato, C. Vitale, M. d'Amato, L. Cecchi, G. Liccardi, et al.. Thunderstorm-related asthma: what happens and why. Clinical and Experimental Allergy Reviews, 2016, 46 (3), pp.390-396. 10.1111/cea.12709 . hal-01314504

\section{HAL Id: hal-01314504 https://hal.sorbonne-universite.fr/hal-01314504}

Submitted on 11 May 2016

HAL is a multi-disciplinary open access archive for the deposit and dissemination of scientific research documents, whether they are published or not. The documents may come from teaching and research institutions in France or abroad, or from public or private research centers.
L'archive ouverte pluridisciplinaire HAL, est destinée au dépôt et à la diffusion de documents scientifiques de niveau recherche, publiés ou non, émanant des établissements d'enseignement et de recherche français ou étrangers, des laboratoires publics ou privés. 


\section{"Thunderstorm related asthma: what happens and why."}

Gennaro D'Amato ${ }^{1}$, Carolina Vitale ${ }^{2}$, Maria D'Amato², Lorenzo Cecchi ${ }^{3}$, Gennaro Liccardi ${ }^{4}$, Antonio Molino ${ }^{2}$, Alessandro Vatrella ${ }^{5}$, Alessandro Sanduzzi ${ }^{2}$, Cara Maesano ${ }^{5}$, Isabella AnnesiMaesano ${ }^{5}$.

${ }^{1}$ Gennaro D'Amato , MD, FAAAAI

Division of Respiratory and Allergic Diseases Department of Chest Diseases High Speciality

A.Cardarelli Hospital, Napoli, Italy

${ }^{2}$ Carolina Vitale, MD, Maria D'Amato, MD, Antonio Molino, MD, Alessandro Sanduzzi MD First Division of Pneumology, High Speciality Hospital "V. Monaldi" and University "Federico II" Medical School Naples, Italy

${ }^{3}$ Lorenzo Cecchi, MD

University of Florence, Florence, Italy; Allergy and Clinical Immunology Section, Azienda Sanitaria di Prato, Prato, Italy

${ }^{4}$ Gennaro Liccardi, MD

Division of Respiratory and Allergic Diseases Department of Chest Diseases High Speciality A.Cardarelli Hospital, Napoli Italy

${ }^{5}$ Alessandro Vatrella, MD

Department of Medicine and Surgery University of Salerno, Salerno, Italy

Cara Maesano PhD

${ }^{6}$ Sorbonne Universités, UPMC Univ Paris 06, INSERM, Pierre Louis Institute of Epidemiology and Public Health (IPLESP UMRS 1136), Epidemiology of Allergic and Respiratory Diseases Department (EPAR), Saint-Antoine Medical School, F75012 Paris, France;

Isabella Annesi-Maesano, MD, DSc, PhD

${ }^{6}$ Sorbonne Universités, UPMC Univ Paris 06, INSERM, Pierre Louis Institute of Epidemiology and Public Health (IPLESP UMRS 1136), Epidemiology of Allergic and Respiratory Diseases Department (EPAR), Saint-Antoine Medical School, F75012 Paris, France;

\section{Corresponding Author \\ IAM}

Epidemiology of Allergic and Respiratory Diseases Department (EPAR) Department, Pierre Louis Institute of Epidemiology and Public Health (IPLESP UMRS 1136), UPMC and INSERM, Saint-Antoine Medical School, 27 rue Chaligny F75571 Paris CEDEX 12, France isabella.annesi-maesano@inserm.fr 


\begin{abstract}
The fifth report issued by the Intergovernmental Panel on Climate Change forecasts that greenhouse gases will increase global temperature as well as the frequency of extreme weather phenomena. An increasing body of evidence shows the occurrence of severe asthma epidemics during thunderstorms in the pollen season, in various geographical zones. The main hypotheses explaining association between thunderstorms and asthma claim that thunderstorms can concentrate pollen grains at ground level which may then release allergenic particles of respirable size in the atmosphere after their rupture by osmotic shock. During the first 20-30 minutes of a thunderstorm, patients suffering from pollen allergies may inhale a high concentration of the allergenic material that is dispersed into the atmosphere, which in turn can induce asthmatic reactions, often severe. Subjects without asthma symptoms, but affected by seasonal rhinitis can also experience an asthma attack. All subjects affected by pollen allergy should be alerted to the danger of being outdoors during a thunderstorm in the pollen season, as such events may be an important cause of severe exacerbations. In the light of these observations, it is useful to predict thunderstorms and thus minimise thunderstorm-related events.
\end{abstract}

Key words: allergic asthma, pollinosis, asthma outbreaks, pollen grains, thunderstorm-related asthma 


\section{Introduction}

The fifth report issued by the Intergovernmental Panel on Climate Change forecasts that greenhouse gases (such as carbon dioxide, methane, and nitrogen dioxide) will increase global temperatures and as a consequence the frequency of extreme weather phenomena including snowfalls, heavy rains, storms, hurricanes, tornadoes and large hail events (1). This fits in with scientists' understanding of the fundamental physics of a warming world. Warmer air carries more moisture, which means that rain falls in heavier bursts. Projections show that future precipitation and storm changes will vary by season and region. Some regions may have less precipitation, some may have more precipitation, and some may have little or no change. The amount of rain falling during heavy precipitation events is likely to increase in most regions, while storm tracks are projected to shift poleward (2). However, because of uncertainty of the projections, the interpretation of how individual hazards will change is open to question.

Thunderstorms generally lead to negative impacts on lives and property. One of the potential impacts in human beings is thunderstorm-related asthma. Thunderstorm asthma is a term used to describe an observed increase in acute bronchospasm cases following the occurrence of thunderstorms in the local vicinity. An increasing body of evidence shows the occurrence of severe asthma epidemics during thunderstorm in the pollen season (3-5) and it is now recognized that thunderstorms are a risk factor for asthma attacks in patients suffering from pollen allergy (3). The frequency of thunderstorm-related asthma might increase because of storm increase. We present here a state of the art of thunderstorm-related asthma.

\section{Thunderstorm associated asthma epidemics: observational evidence}

Several epidemics of asthma have been reported following thunderstorms in various geographical zones (6-14), predominantly in Europe and Australia (table 1).

The largest asthma outbreak ever recorded was in London, coinciding with a heavy thunderstorm on June 24, 1994. A large increase in the number of visits for asthma at the emergency departments of London and the southwest of England was observed. Several of the patients who experienced an asthma attack were not known to be asthmatics or were known to be sensitised to pollen and had been affected only by seasonal rhinitis, (6). During a 30-h period beginning 18:00 on June 24, 1994, 640 patients with asthma or other airways disease (283 of whom were not known to be asthmatic and 357 of whom were affected only by seasonal rhinitis) attended several emergency departments, nearly 10 times the expected number of 66 patients. In total, 104 patients were admitted, including five to an intensive care unit, 574 patients whose 
asthma was attributable to the thunderstorm). Evidence of another asthma outbreak in the UK, was provided by Packe and Ayres (7) at the East Birmingham Hospital (UK) on July 6 and 7, 1983. This is one of the first observations of the link between thunderstorms and asthma outbreaks. It was described as a remarkable increase in the number of asthma emergency department admissions during the hours of a thunderstorm. In a 36-h period, 26 asthma cases were treated in the emergency department, compared with a daily average of two or three cases in the days preceding the outbreak. Other asthma outbreaks during thunderstorms have been described in Australia. In Melbourne, two large asthma outbreaks coincided with thunderstorms (8). In Wagga Wagga (Australia), 215 asthmatic subjects attended the local emergency department, 41 of whom required admission to hospital (9). In south eastern Australia, it was observed that the incidence of excess hospital attendances for asthma during late spring and summer was strongly linked to the occurrence of thunderstorm outflows and demonstrated that the arrival of a thunderstorm outflow was accompanied by a large increase in the concentration of ruptured pollen grains in ambient air (9).

To date, among pollens, only grass, Parietaria and olive pollen have been suggested as possible triggers in thunderstorm-related asthma (10). In Naples (Italy), a thunderstorm-related asthma episode was observed on June 3 and 4, 2004, when six adults and one child received emergency treatment. All patients showed allergic respiratory symptoms upon exposure to Parietaria pollen but were not sensitised to grasses. Parietaria is an Urticacea that is widespread in the Southern regions of Italy with a spring and summer pollen season that is, in part, coexistent with that of grasses (5). During the thunderstorm on June 3, 2004 , the concentration of airborne Parietaria pollen grains was particularly high, with a peak of 144 grains $/ \mathrm{m}^{3}$, whereas air pollution levels for both gaseous and particulate components based on the hourly concentrations of nitric dioxide, ozone and respirable particulate matter were not particularly high (11). More recently, Losappio et al. (12) observed 20 patients with allergic sensitisation to Olea pollen brought to an emergency department in Barletta, Italy, for sudden and severe asthmatic symptoms in May 2010 following a violent thunderstorm that occurred following a very hot morning (mean temperature: $29^{\circ} \mathrm{C}$ ).

A similar phenomenon has been suggested for moulds (12) after the observation of a possible key role of sensitisation to Alternaria species in thunderstorm related asthma (5). Of note, most of the aforementioned asthma epidemics were observed while levels of chemical air pollution were below or similar to levels in a control period.

Although the value of these studies can be criticised because of the small sample size, two studies based on larger samples sizes in two North American countries support the existence of thunderstorm-related asthma cases. In Ottawa, Canada, hospital emergency department 
visits for asthma between 1992 and 2000 were identified and their relationships to fog, thunderstorms, snow, and liquid and freezing forms of precipitation were investigated. In total, there were 18,970 asthma visits among children aged 2-15 yrs and their occurrence was significantly associated with summer thunderstorm activity relative to summer periods with no activity (OR 1.35, 95\% Cl 1.02-1.77) (14). In Atlanta, GA, USA, 24,350 emergency department asthma visits occurred on days following thunderstorms (out of 215,832 emergency department asthma visits during the study period) (15). A statistically significant association was observed between daily counts of asthma emergency department visits and thunderstorm occurrence $(p=0.001)$. Overall, the number of emergency department asthma visits was $3 \%$ higher on days following thunderstorms. Rainfall and gusts of wind played a role, with higher risks of asthma associated with rainfall and strong gusts.

\section{Possible mechanism for thunderstorm-related asthma}

Much remains to be discovered about the relationship between asthma attacks and thunderstorms, but there is reasonable evidence of a causal relationship between the two when observing patients suffering from pollen allergies. Much of the evidence has shown that the asthma epidemics related to thunderstorms are limited to seasons when there are high atmospheric concentrations of airborne allergenic pollens. Subjects with pollen allergy who stay indoors with the window closed during thunderstorms are not involved; further there are no observations on the involvement of asthma in non-allergic subjects (3-5). Thunderstorms can concentrate pollen grains at ground level which may release allergenic particles of respirable size into the atmosphere after their rupture by osmotic shock. During the first 20-30 minutes of a thunderstorm, patients suffering from pollen allergy may inhale a high concentration of the allergenic material that is dispersed into the atmosphere. This is due to dry updrafts that, during a thunderstorm, entrain whole pollens into the high humidity at the cloud base where they may rupture, followed by cold downdrafts that carry pollen fragments (pollen grains are too large to penetrate the deeper airways) to ground level where outflows distribute them. Due to strong electric fields that develop during thunderstorms, positive ions are released from the ground and could attach to particles and/or electric charge may enhance pollen rupture, thus, enhancing bronchial hyper-responsiveness (16). This hypothesis was supported by Buters et al.' work that showed that at higher humidity, more allergens, from pollen or smaller particles, are available in ambient air. These allergens can likely penetrate deeper into the lung, provoking more severe symptoms (17). 
It has been suggested that grass pollen starch granules are the most likely cause of associations between thunderstorms and asthma. Suphioglu et al. (18) showed that rye grass pollen grains contain a large amount of starch granules coated with allergens. After being ruptured in rainwater by osmotic shock, each grain can release 700 starch granules, which are small enough to penetrate the airways and trigger asthma attacks in previously sensitised subjects. Later Taylor et al. (16) hypothesized that the turbulent front of the advancing outflow releases more pollen from flowering grasses and grass pollen may release large amounts of paucimicronic allergenic particles, i.e. cytoplasmatic starch granules containing grass allergens (allergen-bearing starch granules), after rupture by osmotic shock during thunderstorms.

Allergen-bearing starch granules obtained upon contact of pollen with water have been shown to create an inhalable allergenic aerosol capable of triggering an early asthmatic response in an experimental study. Starch granules were shown to be recognised by pollen-sensitised rats sera and to trigger lymph node cell proliferation in these rats (19).

In addition to grass pollen, some data implicate Parietaria pollen in thunderstorm related asthma. Parietaria pollen does not have starch granules in the cytoplasm, but can release other paucimicronic cytoplasmic components carrying allergens (3-20).

Due to their very small size $(<5 \mathrm{~mm})$, these microparticles can penetrate the lower airways inducing the occurrence of bronchial allergic symptoms. Abou Chakra (21) showed that in rats, pollen cytoplasmic granules (PCGs) containing allergens are able to deeply penetrate the respiratory tract and induce local and strong allergic and inflammatory responses more closely linked with asthma- than rhinitis-related allergic symptoms. The proliferative responses of lymph node cells were similar in PCG- and pollen-sensitised rats. IgE and IgG1 levels were higher in pollen- than PCG-sensitised rats. However, eosinophils, lymphocytes and pro-allergy cytokines in bronchoalveolar lavage fluid were higher in PCG- than pollen-sensitised rats.

There is also evidence that increased amounts of pollen, as well as increased mould spore counts, have been found during thunderstorms $(5,10,22$,).

In the case of fungal spores, such as Alternaria, the prerequisites for asthma epidemics associated with thunderstorms have been described as follows $(12,23): 1)$ a sensitised, atopic, asthmatic individual; 2) a sudden, large allergen exposure; 3) a large-scale thunderstorm with cold outflow occurring at a time and location during an allergen season in which large numbers of asthmatics are outdoors; and 4) sudden release of large amounts of respirable allergenic fragments, particularly fungal spores such as Alternaria.

In a recent study, Grinn-Gofroń et al. (24) created a predictive model for hourly concentrations of atmospheric Alternaria and Cladosporium spores on days with summer storms in Szczecin (Poland) based on meteorological conditions. They demonstrated statistically significant 
relationships between spore concentration and meteorological parameters: positive for air temperature and ozone content while negative for relative humidity. Artificial neural networks (ANN) were used to assess forecasting possibilities. Good performance of ANN models in this study suggest that it is possible to predict spore concentrations from meteorological variables $2 \mathrm{~h}$ in advance and, thus, warn people with spore-related asthma symptoms about the increasing abundance of airborne fungi on days with storms (24).

Recently Kim et al. (25) hypothesized that the innate eosinophilic response to Alternaria extract may enhance lung inflammation induced by ryegrass. It has been shown that a single exposure to Alternaria extract in ryegrass-sensitized and -challenged mice enhances the type 2 lung inflammatory response, including airway eosinophilia, peribronchial infiltrate, and mucus production, possibly through Th2 cell recruitment and ILC2 expansion. If translated to humans, exposure to both grass pollen and Alternaria may be a potential cause of thunderstorm-related asthma (25).

Although there is an increasing interest to investigate thunderstorm-related asthma, published data are scant (26-33).

\section{Is there a causal link between thunderstorm and asthma attacks?}

To better understand the association between thunderstorm and asthma attacks in patients suffering from pollen allergy, we used an epidemiological approach applying Hill's criteria of causality (table 2), the criteria conditions necessary to provide adequate evidence of a causal relationship between a risk factor and a consequence (34). Most of Hill's criteria support the hypothesis of a causal link of thunderstorms to asthma attacks through pollen exposure, but there is still some uncertainty (4).

Temporal relationship, strength, dose-response relationship, consistency, plausibility, consideration of alternate explanations and specificity are fulfilled. Instead of, there are only limited, in particular experimental data, which challenges direct evidence on the intervention of pollen as well as the specificity criterion according to which a single putative cause produces a specific effect. Only in few studies, the concentration of pollen and moulds eventually in connection with air pollutant materials was shown to be closely related to meteorological phenomena (such as storms, hurricanes, and floods), and to affect the incidence of allergic diseases in accordance with weather changes (35). For example, Marks et al. (22) demonstrated that the arrival of a thunderstorm outflow was accompanied by a large increase in the concentration of ruptured of pollen grains in ambient air. Pulimood et al. (23) reported that in the thunderstorm in which they studied, asthma epidemics were associated with 
increased levels of Alternaria, Cladosporium and Didymella spp. Similarly, Anderson et al. (36), observed that during a thunderstorm period the pollen concentration in the air decreased, but the concentration of mold spores increased, leading to an increase in the incidence of asthma. Langenberg et al. (37) showed that as temperature and wind speed increased and humidity decreased, the concentration of mold spores in the air increases. Recently, the European HIALINE project (www.hialine.eu) showed that although pollen count and allergens in ambient air follow the same temporal trends, a 10-fold difference can exist in allergen potency of birch pollen, so that symptoms might be difficult to correlate with actual pollen counts, but could correlated with allergen exposure (38).

\section{Is it possible to predict thunderstorm related asthma?}

Individual thunderstorms have coincided with up to 10-fold rises in asthma admissions and a small increase in asthma admissions has been reported to be associated with thunderstorms in general (39). Depending on the size of the population at risk, thunderstorm related asthma outbreaks may threaten the operative capacity of health services, as was the case in London in 1994 and $2013(6,40)$. Clearly, not all thunderstorms are associated with asthma epidemics. Therefore, even if there is a causal link between thunderstorms and asthma, there must be other factors which interact with thunderstorms that would need to be taken into account in building any early warning system for asthma epidemics (40).

The roles of accompanying meteorological features and aeroallergens, such as pollen grains and fungal spores, have been studied in an effort to identify which risk factors could predict the occurrence of asthma outbreaks. Newson et al. (26) identified 56 asthma epidemics defined as periods of exceptionally high asthma admission counts compared with predictions of a loglinear auto-regressive model. Of note, the authors measured pollen counts and, for the first time, thunderstorms using densities of spherics (lightning flashes). However, the data from Newson et al. (26) do not support the possibility of predicting asthma outbreaks by using meteorological data and pollen counts. In their study, thunderstorms and high grass pollen levels preceded asthma epidemics more often than expected by chance. However, most thunderstorms, even following high grass pollen levels, do not precede epidemics and most epidemics are not associated with thunderstorms or unusual weather conditions but to other factors, such as respiratory infections. One limit of this study is the exclusive use of grass pollen and the exclusion of the other aeroallergens. The potential inclusion of a wider range of aeroallergens to early warning for thunderstorm asthma deserves further assessment. Despite 
the increasing amount of data on the allergen content of ambient air published in recent years $(27,28)$, to date pollen or mould allergens have never been quantified during a thunderstorm. Therefore, early warning systems for thunderstorm asthma currently have limited practical applications $(4,38)$. The European HIALINE project (www.hialine.eu) could take a step forward in the development of early warning systems for thunderstorm asthma providing conclusive data on the actual changes in the allergenic load of the air during such an extreme precipitative event (27).

\section{Conclusions}

There is increasing evidence that thunderstorms trigger epidemics of asthma during the pollen season by washing down pollen grains and concentrating them in a band of air at ground level. Cytoplasmic granules of small size are released from the pollen grains by contact with rainwater. As a consequence, at the onset of a thunderstorm, there is a high respirable allergen load in the air and these conditions might expose susceptible subjects to a high increase of pollen allergens in the atmosphere (1-7,22,33-40). Pollen allergic patients who encounter the allergenic cloud would be more susceptible to undergo an asthma attack. The characteristics of described outbreaks of thunderstorm-associated asthma are summarized in table 3 . The thunderstorm-asthma outbreaks are characterized, at the beginning of thunderstorms by a rapid increase of visits for asthma in general practitioner or hospital emergency departments. Unfortunately, identifying risk factors to be used to build any early warning system for asthma outbreaks has been shown as difficult (32). However, the potential of using emergency department attendance data has been shown as useful in London (33). A statistically significant spike in asthma attendances in two EDSSS emergency departments in London was detected on 23 July 2013, coinciding with a series of large violent thunderstorms across southern England. There was also an increase in the reported severity of these attendances.

In the light of the above, subjects affected by pollen allergy, as well as subjects affected by seasonal rhinitis without asthma symptoms, should be alerted to the danger of being outdoors during a thunderstorm in the pollen season, as such events may be an important cause of severe exacerbation of asthma (1-7,22,34-40). Such a risk is likely to increase in relation with climate change and related extreme events. 


\section{References}

1) Intergovernmental Panel on Climate Change. Intergovernmental Panel on Climate Change; : 2014 IPCC fifth assessment report: climate change

2) Meel G.A.T.F. Stocker W.D. Collins et al. Global Climate Projections in Climate Change 2007:The Physical science basis Contribution of Working Group I to the Fourth Assessment Report of the Intergovernmental Panel on Climate Change [Solomon, S., D. Qin, M. Manning, Z. Chen, M. Marquis, K.B. Averyt, M. Tignor and H.L. Miller (eds.)]. Cambridge University Press, Cambridge, United Kingdom and New York, NY, USA.

3) D'Amato G, Liccardi G, Frenguelli G. Thunderstorm-associated asthma in pollinosis patients. Allergy 2007; 62: 11-16.

4) D'Amato G, Cecchi L, Annesi-Maesano I. A trans-disciplinary overview of case reports of thunderstorm-related asthma outbreaks and relapse. Eur Respir Rev. 2012 Jun $1 ; 21(124): 82-7$.

5) D'Amato G, Liccardi G, Gilder JA, et al. Thunderstorm-associated asthma in pollinosis patients. 2005, BMJ. www.bmj.com/rapidresponse/2011/10/30/thunderstormassociated-asthma-pollinosispatients.

6) Diventa, Venables KM, Allitt U, Collier CG, et al. Thunderstorm-related asthma epidemic 24/25 June 1994. Clin Exp Allergy 1997; 27: 725-736.

7) Packe GE, Ayres JG. Asthma outbreak during a thunderstorm. Lancet 1985; 2: 199 204.

8) Bellomo R, Gigliotti P, Treloar A, et al. Two consecutive thunderstorm associated epidemic of asthma in Melbourne. Med J Aust 1992; 156: 834-837.

9) Girgis ST, Marks GB, Downs SH, et al. Thunderstorm-associated asthma in an inland town in southeastern Australia. Who is at risk? Eur Respir J 2000; 16: 3-8.

10) D’Amato G, Cecchi L, Liccardi G. Thunderstorm-related asthma: not only grass pollen and spores. J Allergy Clin Immunol 2008; 121:537-538.

11) D'Amato G, Ruffilli $A$, Ortolani C. Allergenic significance of Parietaria (pellitory-of-thewall) pollen. In: D'Amato G, Spieksma F, Bonini S, eds. Allergenic Pollen and Pollinosis in Europe. Oxford, Blackwell Scientific Publications, 1991; pp. 113-118.

12) Losappio L, Heffler E, Contento, et al. Thunderstorm-related asthma epidemic owing to Olea Europea pollen sensitization. Allergy 2011; 66: 1510-1511.

13) Nasser SM, Pulimood TB. Allergens and thunderstorm asthma. Curr Allergy Asthma Rep 2009; 9: 384-390.

14) Villeneuve $P J$, Leech J, Bourque D. Frequency of emergency room visits for childhood asthma in Ottawa, Canada: the role of weather. Int J Biometeorol 2005; 50: 48-56. 
15) Grundstein A, Sarnat SE, Klein M, et al. Thunderstorm associated asthma in Atlanta, Georgia. Thorax 2008; 63: 659-660.

16) Taylor PE, Hagan R, Valenta R, et al. Release of allergens in respirable aerosols: a link between grass pollen and asthma. J Allergy Clin Immunol 2002; 109: 51-56.

17) Buters J, Prank M, Sofiev $M$ et al. Variation of the group 5 grass pollen allergen content of airborne pollen in relation to geographical location and time in season. J Allergy CLin Immunol2015 (in press)

18) Suphioglu C. Thunderstorm asthma due to grass pollen. Int Arch Allergy Immunol 1998; 116: $253-260$.

19) Motta A, Peltre G, Dormans JA, et al. Phleum pratense pollen starch granules induce humoral and cell-mediated immune responses in a rat model of allergy. Clin Exp Allergy 2004; 34: 310-314.

20) Jato V, Rodrıguez-Rajo FJ, Gonzalez-Parrado Z, et al. Detection of airborne Par j 1 and Par $\mathrm{j} 2$ allergens in relation to Urticaceae pollen counts in different bioclimatic areas. Ann Allergy Asthma Immunol 2010; 105: 50-56.

21) Abou Chakra O, Rogerieux F, Poncet $P$, et al. Ability of pollen cytoplasmic granules to induce biased allergic responses in a rat model. Int Arch Allergy Immunol 2011; 154: 128-136.

22) Marks GB, Colquhoun JR, Girgis ST, Koski MH, Treloar ABA, Hansen Pet al. Thunderstorm outflows preceding epidemics of asthma during spring and summer. Thorax 2001;56:468-471

23) Pulimood TB, Corden JM, Bryden $C$, et al. Epidemic asthma and the role of the fungal mold Alternaria alternate. J Allergy Clin Immunol 2007; 120: 610-617

24) Grinn-Gofroń A, Strzelczak A.Changes in concentration of Alternaria and Cladosporium spores during summer storms. Int J Biometeorol. 2013;57:759-68.

25) Kim HK, Lund S, Baun R et al.Innate Type 2 Response to Alternaria Extract Enhances Ryegrass-Induced Lung Inflammation.Int Arch Allergy Immunolo. 2013 Nov 30;163:92105.

26) Newson R, Strachan D, Archibald E, et al. Acute asthma epidemics, weather and pollen in England, 1987-1994. Eur Respir J 1998; 11:694-701.

27) Newson R, Strachan D, Archibald E, Emberlin J, Hardaker P, Collier C. Effect of thunderstorms and airborne grass pollen on the incidence of acute asthma in England, 1990-1994. Thorax 1997;52:669-670.

28) De Linares C, DI'az de la Guardia C, Nieto Lugilde D, et al. Airborne study of grass allergen (Lol p 1) in different-sized particles. Int Arch Allergy Immunol 2010; 152: 49_ 57.

29) Suphioglu $C$, Singh MB, Taylor $P$, Knox RB. Mechanism of grass-pollen-induced asthma. Lancet 1992;339:569-572. 
30) Knox RB. Grass pollen, thunderstorms and asthma. Clin Exp Allergy 1993;23:354-356

31) Celenza A, Fothergill J, Kupek E, Shaw RJ. Thunderstorms associated asthma: a detailed analysis of environmental factors. BMJ 1996;312:604-607

32) Wallis DN, Davidson AC, Weilch J, et al. Clinical and immunological characteristics of patients with thunderstorm asthma. Eur Respir J 1995; 8: Suppl. 19, 500s.

33) Elliot AJ, Hughes HE Hughes TC et al. The impact of thunderstorm asthma on emergency department attendances across London during July 2013. Emerg Med J 2014Aug;31(8):675-8. doi: 10.1136/emermed-2013-203122. Epub 2013 Oct 7.

34) Anto JM, Sunyer J. Thunderstorms: a risk factor for asthma attacks. Thorax 1997; 52 : 669-670.

35) Hill AB. The environment and disease: association or causation? Proc R Soc Med 1965; 58: $295-300$.

36) Shea K.M. Truckner R.T. Weber RW. Peden D.B. Climate change and allergic disease. J Allergy Clin Immunol 2008 Sep ;122(3):443-453

37) Anderson W, Prescott GJ, Packham S, et al. Asthma admissions and thunderstorms: a study of pollen, fungal spores, rainfall and ozone. QJM 2001 Aug 94(8):429-433

38) Langenberg WJ, Sutton JC, Gillespie TJ. Relation of weather variables and periodicities of airborne spores of Alternaria dauci. Phytopathology $1977 \mathrm{Jul} ; 67(7): 879 e 83$.ù

39) Buters JT, Weichenmeier I, Ochs $S$, et al. The allergen Bet v 1 in fractions of ambient air deviates from birch pollen counts. Allergy 2010; 65: 850-858.

40) Dabrera G, Murray V, Emberlin $\mathrm{J}$ et al. Thunderstorm asthma: an overview of the evidence base and implications for public health advice, Q J Med 2013; 106:207-217 
Tab 1. Thunderstorm-asthma: which evidences?

\begin{tabular}{|c|c|c|}
\hline \multicolumn{3}{|r|}{ Tab 1. Thunderstorm-asthma: which evidences? } \\
\hline Year & Country & Evidences \\
\hline 1993 & UK & 26 sudden cases of asthma attacks in relation to thunderstorms \\
\hline 1992 & Australia & $\begin{array}{l}\text { Late spring thunderstorms in Melbourne can trigger epiderrics of astrma attacks (five to } 10 \text {-fold } \\
\text { rise) }\end{array}$ \\
\hline 1997 & UK & $\begin{array}{l}\text { Astrma or other ainways disease hospital visits. } 640 \text { cases who attended during a } 30 \text {-h period on } \\
\text { June } 1994 \text {, nearly } 10 \text { imes expected number }\end{array}$ \\
\hline $1992-2000$ & Canada & $\begin{array}{l}18970 \text { hospital ED asthma visits among children } 2-15 \text { yrs of ageSummer thunderstorm actovity } \\
\text { was associated with an OR of } \\
1.35 \text { (95\% Cl 1.02-1.77) relative to summer periods with no actovity }\end{array}$ \\
\hline 1993-2004 & USA & $\begin{array}{l}215832 \text { asthma ED visits; } 24350 \text { of these visits accurred on days following thunderstorms, } \\
\text { Significart associabon between daily courts of asthma ED visits and thunderstom occurence } \\
\text { Astrma visits were } 3 \% \text { highes on days following thunderstorms. }\end{array}$ \\
\hline 2000 & Australia & $\begin{array}{l}\text { Astrma visits during thunderstoems } \\
\text { History of hay fever and alergy to rye grass are strong predctors for astma exacerbation during } \\
\text { thunderstorms in spring }\end{array}$ \\
\hline 2001 & Australlia & $\begin{array}{l}\text { The incidance of excess hospital attendances for asthma dring } \\
\text { late spping and summer was strongly iriked to the occurrence } \\
\text { of thunderstorm oufliows }\end{array}$ \\
\hline 2002 & UK & 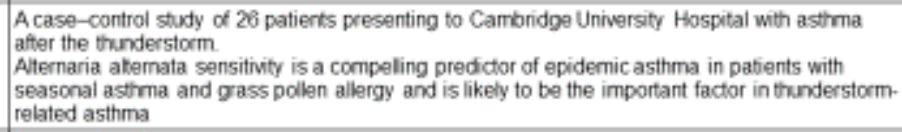 \\
\hline 2004 & Italy & Six cases of thunderstorm-related asthma because of polen (Paretaria) \\
\hline 2010 & Italy & 20 cases of thunderstorm-related asthma because of polen (olive tree) \\
\hline 2010 & Australlia & 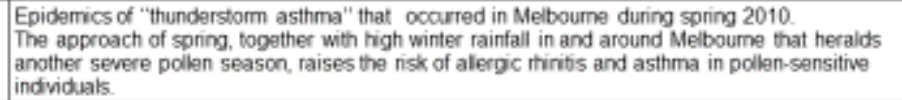 \\
\hline
\end{tabular}


Tab. 2 Hill's criteria applied to thunderstorm related asthma

\begin{tabular}{|c|c|}
\hline Hail's crimecia & 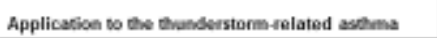 \\
\hline 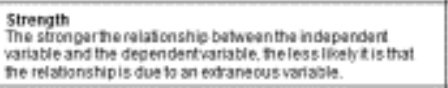 & 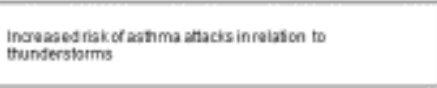 \\
\hline 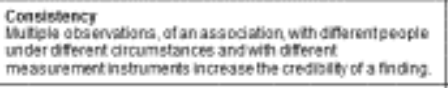 & 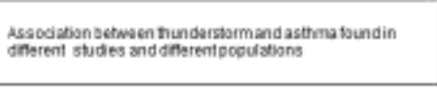 \\
\hline 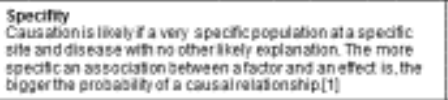 & 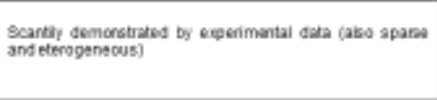 \\
\hline 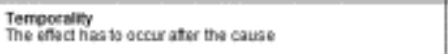 & 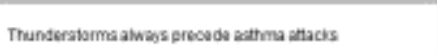 \\
\hline 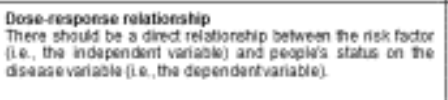 & 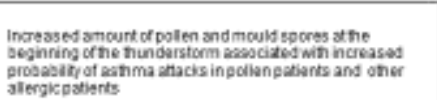 \\
\hline 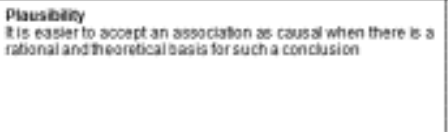 & 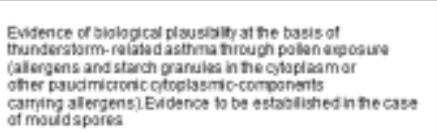 \\
\hline 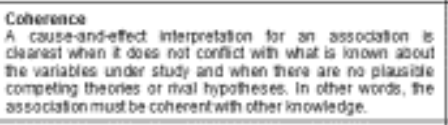 & 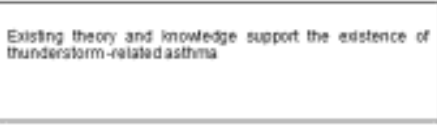 \\
\hline 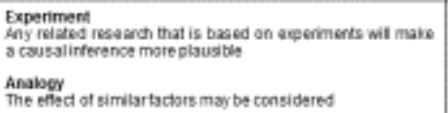 & 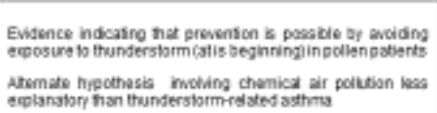 \\
\hline
\end{tabular}




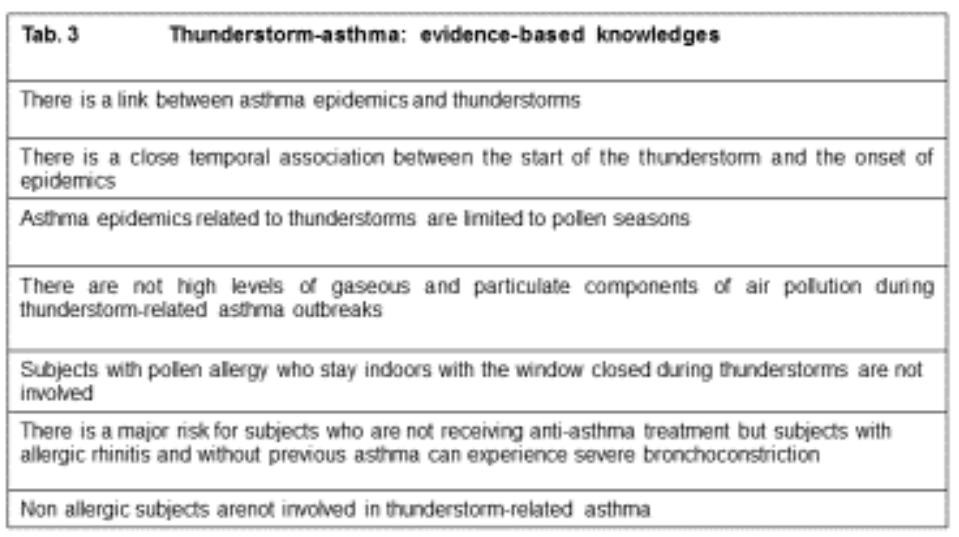

